\title{
THE IMAGE OF THE POET MIHAI EMINESCU IN THE LITERARY DICTIONARIES
}

\author{
Petra Denisa Tcacenco \\ Lingvistic and Literary Studies \\ (@) $\odot \Theta \Theta$ \\ Faculty of Letters, Babeş-Bolyai University, Cluj, Romania \\ Email address: denisa_petra@yahoo.com
}

\begin{abstract}
Mihai Eminescu is known as the Romanian national poet, the most important writer of the XIX ${ }^{\text {th }}$ century in Romanian literature, whose writings have been intensely interpreted since his poetic debut. Therefore, this paper proposes a study of the way the literary dictionaries build the image of "the national poet". This identity construct is significant to our investigation because it influences the interpretation of the poet figure through history. In order to have a wider view of the problem, we consulted a series of literary dictionaries and, also, dictionaries for students use to see how the figure of Eminescu is taught in schools. Moreover, we did not put aside foreign dictionaries, which bring a more objective perspective to the issue. The majority of Romanian dictionaries alter the poet's portrait in favor of a "national construct", created partly by the use of rhetoric figures. Another way of composing him a deformed image is accomplished by writing subjective and opaque interpretation of his poems. Consequently, such hermeneutics focuses on developing a myth that reflects mainly the way Romanians as nation want to be recognized and remembered.

Keywords: national poet, literary history, Mihai Eminescu, romanticism, literary dictionaries
\end{abstract}

Mihai Eminescu was a writer of poetry, drama, fiction and also a journalist. He was born in 1850 in a city called Botoşani, in Moldavie, Romania and died in 1889 in Bucharest. Until today, he remains known in the literary history as the "Romanian national poet", the most important writer of the XIX ${ }^{\text {th }}$ century in our literature. This identity construct influenced the way Mihai Eminescu was interpreted through the course of time. His first published poem was an occasional one, which appeared in a brochure called Lăcrămioarele invățăceilor gimnasişti din Cernăuți la mormîntul preaiubitului lor profesoriu Arune Pumnul [The Tender Tears of the Cernăuți Gymnasium Young Students at The Grave of Their Beloved Magister Arune Pumnu]. A collection of his poems was published by Titu Maiorescu, an important critic of that time, in 1883, without the poet's consent, Eminescu seeing this as an act of intrusion into his projects. His intention was to gather his poems in a volume called "Moonlight". The critic Ioana Em. Petrescu, a specialist in Eminescu poetry, divided them into three stages: in the first one, between 1866-1870, the poet is influenced by his predecessors, the "paşoptists", name given after the national-ideology developed during the 1848's revolution. But, 
instead of following stubbornly their model, the poet changes the perspective, often using their rhetorical figures to invalidate the ideas expressed in poems. There is a second stage, during 1870-1881, when the poet imagines a Schopenhauerian view of the world, building compensative universes in order to find a refuge in poetry, in history or love. Finally, in the third stage, between 1881-1883, the poet transgresses the romanticism, realizing a synthesis between a Hegelian and a Schopenhauerian vision of the world. He now manifests mistrust in the creative powers of the poetic language, writing poems with very simple rhetorical structures, replacing the figures of speech with figures of construction and obliging the words to follow the strict rules of the fixed forms of poetry.

However, the manner in which the literary dictionaries build the poet's image is the principal aim of this paper. The poet's portrait seems to be created by the history it transcends, which changes its appearance and, by consequence, makes Eminescu a perpetual source of identity tips. How this identity construct developed in the literary history and what are the instruments that form it become the main questions of this study. More precisely, we have in view to search for answers in the Romanian literary dictionaries, in some foreign dictionaries and also Romanian dictionaries for student use. We intend to analyze each dictionary, following the configuration of two main sections: biography and literary works of the poet. Regarding the instruments that form Eminescu's figure, they refer mainly to elements of composition, rhetoric figures or syntactic tips that compose the articles.

In Dicționarul literaturii române de la origini până la 19001979 [Dictionary of Romanian Literature from origins until 1900 1979] Mihai Eminescu appears represented as a poet. The biographic data is detailed, it begins with information about his ancestors, like his great-grandfather Petrea Iminovici to the grades he took in school. The author's discourse is filled with subjective commentaries that transform the figure of the poet into a fictional character: "Like Ion Creangă, his childhood will be covered in a fairy tale picture, and to this connection with nature and people, to the first love, the poet will always return with kindness, finding here silence and reflection" (Stănuța, 1979, p. 312). The language adopted is subjective, impressive, even poetic, the critic is using metaphors to speak about the travels of the poet through the country: "From Blaj, driven by a demon of instability, the need of knowing his country and the beauty of the popular language, he goes to Sibiu" (Stănuța, 1979, p. 313). The period when he studied abroad, in Vienna, is treated with a constant concern for finding an excuse for any conduct which could alter an idealized image of the poet: "the multitude of projects in the epoch, period of intense creation, explains the neglect of his systematic studies" (Stănuța, 1979, p. 314). When the poet refuses to finish a PhD and accept a job in Romania, the reason given in the dictionary is destiny, not his own choice. Concerning his controversial death, according to the dictionary, it is surveyed after physical and psychical decay.

With regard to his literary work, one is connected with his genius and the knowledge of the people: "The works of Eminescu, the greatest Romanian poet, can be explained not only by an extraordinary talent, but also by an unusual aspiration to knowledge, a rare capacity to assimilate the spiritual values, traits dominated by the awareness of his creative vocation. His personality is composed of elements like a pro- 
found knowledge of the language and the psychology of the peasants, of traditions and customs, of his own people's mentality, which gives his writings that nationality mark, the specificity within the European and universal values"' (Stănuța, 1979, p. 318). We can observe here how the portrait of the poet and his capacity to retain knowledge are exaggerated and universalized, making him embrace many fields of culture, from the Antic philosophy to a wide universal literature (including Romans, Greek, French, Italian, Spanish, German, Danish, Norwegian, Hungarian, Lithuanian, Russian, Indian). The dictionary article focuses mainly on the social dimension of his poems, bringing forth motifs like "love of country", "the glorious past", leaving aside others, thus, offering the public an incomplete image of his imaginary universe.

Again, some of the negative aspects of his philosophy are interpreted in a positive way, for example, the pessimism of the poet is seen as a meditation. Eminescu's visions of life are, in this manner, denaturized. About the themes "nature" and "love" it is said that: "the registry of Eminescian love is maybe the widest and most various in all national literature and one of the originals in world literature" (Stănuța, 1979, p. 325), which is, again, an exaggeration. About the most known poem of Eminescu, Luceafărul [The evening star], we find out in the same idealized way of commentaries that: it "is a symphony with celestial sounds born from that single osmosis between the struggle of a genius existence and the spiritual heritage of an entire nation" (Stănuța, 1979, p. 327). This does not add anything regarding the poem's substance, but makes it difficult to understand why it is validated in such a hyperbolized way. In "Mortua est"! the tragedy of the poet's beloved one's death is treated as a common subject, seen it as the destiny of everyone. Also, the contemplative discourse of the poet is not the result of abstract concepts like pessimism, negation, hopelessness, but it refers, on the contrary, to the blows of faith and constructive feelings. The way the article finishes shows a clear intention on the part of the author to praise the national culture through the figure of the poet: "By the genius of his talent, by the unprecedented power of assimilating the elements of national and universal culture, the Eminescian poetry is a unique synthesis between the individual value and the creative force of a nation, the supreme expression of the Romanian spirituality. His creations, like a sublime mark of his dramatic life, have as coordinates the drama of a genius, the meditation of life and death, love like a fundamental element of the existence, the organic refusal of the evil ghost, the nostalgia after unity, harmony and beauty" (Stănuța, 1979, p. 329).

In Dictionarul general al literaturii române 2012 [General dictionary of Romanian literature 2012] Mihai Eminescu appears introduced as poet, writer of fiction, drama and journalist. Regarding the biographic data, we can observe less subjective comments, but the quantity of information is kept (examples about the grandfather of the poet or about his brothers' lives). What differs is a new, objective perspective in presenting the events of his life, with a simplified syntax reduced to short and dynamic sentences. The cause of his death is the journalistic work that exhausted him. The poetry is organized in terms of quantity: pages written and publications. So, we find out that in 1866-1869 he published 28 pages from 92, in 1870-1874, 200 pages, been published 35 , in 1875-1879, 316 pages, published just a quarter, in 1880-1883, 202 pages, appeared just a half. The poems are classified after the myth they imagine: the myth of creation 
and death of the universe, the history myth, the myth of the old teacher who read "the opposite sign", the erotic myth, the oneiric myth, the myth of returning to elements, the myth of the Creator. The comments are embroidered with superlatives, the critic is in awe when he is talking about the "extraordinary verse" he is reading. The conclusion is given to the other critics: Titu Maiorescu, G. Călinescu, Tudor Arghezi, Perpessicius, Tudor Vianu, Rosa del Conte, Edgar Papu, Ioana Em. Petrescu.

In Dictionarul esential al scriitorilor români 2000 [The essential dictionary of Romanian writers 2000] Mihai Eminescu is presented as poet, writer of fiction and journalist. We observe a reduction of the biographic information concerning his ancestors, which are presented in an objective and succinct way. His poems are interpreted in correlation with the "cosmologic model" (the rapport of the human with the universe) that relates to the stages of creation. Thus, in his first poems: De-aş avea... [If I had..], O călărire in zori [A riding in the morning], La Heliade, [To Heliade] he continues his predecessors' traditions, but he reorganizes the platonic universe. The next stage of development starts with the crises of thought in poems like Amicului F.I. [To the friend F.I], Melancolie [Melancholy], Epigonii [The Epigons] when divinity is the Evil, the object of damnation in Mureşanu, [Mureşanu], Rugăciunea unui dac [The prayer of a dac], Demonism [Demonism] and the demonic heroes aspire to recuperate the lost harmony imagining new universes (dream, love, poetry and history). The third stage of creation is Kantian, when the birth of the world means the rebel awakening of a non-existence that was sleeping. Now, existing is possible as long as the poet's mind thinks the world. As a consequence, the worlds that are no more sustained by the power of mind die, as in Memento mori [Memento mori]. The imagination of the poet passes across the ages creating a mythic age in Dacia [Dacia], a heroic one in Scrisoarea a III- $a$ [The third letter] and a depraved present in the satiric verses of Scrisoarea a III-a [The third letter]. The final part is dedicated to the elegies interpreted through the relation between remembrance and forgetfulness. The oblivion is "the law which the tragic conscience lucidly assumes for itself in a universe where the gods take refuge in nonexistence, but still condemn the world to being, creating through thinking their figure and history" (Zaciu, Sasu, \& Papahagi, 2000, p. 302).

The dictionaries used for students build an image of a poet-genius. Thus, in the Dictionar de literatură română şi universală. Autori. Opere. Personaje pentru elevi: 2008 [Dictionary of Romanian and universal literature. Writers. Works. Fictional characters for students 2008], Mihai Eminescu is the greatest Romanian poet, an expression which has become a well known cliché today. The biographic data is turned into a fabulous story, so the birthplace of the poet became a dream space. The less known terms appear in the dictionary without being explained, such as: Eminescu applied for the Faculty of Philosophy and Law as "extraordinary student". Between 1872-1874 is an "ordinary student" in Berlin. The cause of death: his activity as a journalist. We are told that on 23 June the first signs of disease appeared, so, he was hospitalized in a sanatorium, being supervised by doctor Sutu, then, years full of suffering followed, with moments of lucidity and, finally, "our great national poet would cease living on 15 June 1889" (Brais, 2008, p. 71).

The dictionary offers less data about his literary writings, the biography covering most of the space. The poems are organized in themes of creation: child- 
hood Fiind băiet păduri cutreieram [As a child I wander in the forests], love poems: Floare albastră [Blue flower], De câte ori, iubito [How many times, my darling], Sara pe deal [Evening on the hill], philosophical meditation poems: Luceafarrul [The evening star], social poems: Impărat şi proletar [Emperor and proletary], satirical poems: Scrisorile [The letters], folkloric poems: Călin [Călin], Revedere [Meeting again], Mai am un singur dor [I have one more wish], patriotic poems: Ce-şi doresc eu ție, dulce Românie! [What are my wishes for you, dear Romania?], Rugăciunea unui dac [The prey of a dac]. The prose is also enumerated with a few titles: Făt-Frumos din lacrimă [The beautiful young from the tear], Sărmanul Dionis [The poor Dionis], Cezara [Cezara] etc.

Another dictionary for students called Dictionar de literatură română. Autori. Opere. Personaje 1997 [Dictionary of Romanian literature. Writers. Literary workings. Fictional characters 1997] introduces Eminescu as the greatest Romanian poet. His first years of life have the nature of legends: "His childhood, shrouded in a fairy tale and poetry like the one of Ion Creangă, that the poet spends at Ipoteşti, is a place full of memories for him, which are evoked later in various ways, either in poetry or prose" (Popescu, 1997, p. 68). The cause of his disease is taken from Dicționarul literaturii române de la origini până la 19001979 [The dictionary of Romanian literature from origins until 1900 1979]: „,exhausting working", ",total commitment", "privations of all kinds". His poetry is organized in themes: "from the lyricism of evoking the childhood Fiind băiet...[Being a young boy..] and the erotic poems: Floare albastră [Blue flower], De câte ori, iubito...[How many times my darling..], from the poems that praise the historical values and culture: Epigonii [Epigons], La Bucovina [To Bucovina] and until the poems of philosophic meditation Sărmanul Dionis [Poor Dionis], Scrisorile [The letters], from the patriotic poems: Ce-şi doresc eu tie, dulce Românie! [What are my wishes for you, dear Romania?], Scrisoarea a III-a [The third letter], Rugăciunea unui dac [The pray of a dac] and until the ones of folkloric inspiration written in a very refined language" (Popescu, 1997, p. 71). Some information is wrong, because Rugăciunea unui dac [Pray of a dac] cannot be part of the theme "poems of great national inspiration". Even if the title can leave the impression of that, the principal theme of the poem is a curse addressed to the Divine Creator and, also, to his own poetic voice. Yes, it is a prayer, but wrapped in an anathema, ironically converted by the poet into its opposite.

The prose is described in the same uplifting language: "his literary writings, display the contours of a creation individualized and, at the same time, eternally human and universal, having an indisputable relevance" (Popescu, 1997, p. 71).

In another dictionary for students entitled Dicționar de scriitori romîni şi străini. Prietenul micului cititor 2004 [Dictionary of Romanian and foreign writers. The friend of the young reader 2004] Mihai Eminescu is presented as a poet, writer of fiction and journalist. The biographic data mark the chronology of his life. There is a part in the article called "Read to find more!" with extra information about the life of the poet (for example, the students can read there about the poet's father who was strict, so he loved his mother more, about his favourite teacher, Aron Pumnul etc). His disease is caused by the intense journalistic activity which affects his health. The author adds to this that in this period he is writing the most valuable poems in the entire Romanian literature: Luceafärul [The evening star] and Scrisorile [The 
letters]. The poetic works are structured thematically in poems about childhood, nature and love, about nation etc. The conclusions are given up to the voice of the critic George Călinescu in the same encomiastic manner: „In this way fade (...) the greatest poet that has been seen in the Romanian land..." (Stroia, \& Barbu, 2004, p. 68). Then, the author adds that for the originality and the value of his poetic works, Eminescu has been named the "evening star of the Romanian poetry and the only poet of its kind", which is another cliché (Stroia, \& Barbu, 2004, p. 68).

In Dictionar de scriitori canonici români 2010 [Dictionary of Romanian canonical writers 2010] the biography covers the principal events in the poet's life. The literary works are considered from different perspectives. Firstly, the poetic imaginary with specific themes and motifs, then, the texts are interpreted, after which, the notion of Eminescianism (the specificity of the poet's poems) is being interrogated along with the poems about the practice of writing poetry. The themes "nature" and "love" are organized as a space of love, death and the cosmic nature that participates in the erotic feeling. In the first stage of creation, love is seen optimistically, while, in the second one, the poet talks pessimistically about this feeling. The poetry is organized thematically in poems inspired by folklore and myths, by the historical past, philosophical ideas, time and cosmos or by the historic and social meditation. The stages of creation are also included in the classification. Eminescu is a national poet because his literary writings express historical values, he is interested in folklore, in the communion human-nature and is universal because of his interest in antic culture, Greek and modern philosophy, the myths of the apparition and extinction of the universe. The final part of the article is short and concise, but not clear enough. We are given a quote from Tudor Arghezi: „Being very Romanian, Eminescu is universal" (Bădărău, 2010, p. 156). What does being "Romanian" mean in this context, the author forgets to explain, leaving just the quotation, as if it is enough for the public to understand the meaning of it. Why the poet is universal just by being "Romanian"? This identity construct "Romanian" is equally with "universality"? Some explanations from the part of the author would have explained the sense of the quote.

Mihai Eminescu - Dicționar encyclopedic 2013 [Mihai Eminescu - The encyclopedic dictionary 2013] edited by Mihai Cimpoi, introduces Eminescu as poet, writer of fiction, drama and journalist. Regarding the biography, the portrait-syntheses is taken from another book, Dictionarul general al literaturii române 2012 [The General Dictionary of Romanian literature 2012], the author adding an extra remark that the study was written in collaboration with Eugen Simion, the coauthor of it. Regarding the personality of Eminescu, a specificity of the poet are "the actions of alliterative projection" (Cimpoi, 2013, p. 51), which refers to the fact that the poet confessed in his manuscripts that he wished to be his brother, Ilie. We do not know what that means, therefore we cannot give an interpretation. What we can say, though, is that the expression used has an impact on the public because of the weight of the specialized words: "alliteration" as something that has terminal sounds that correspond, and "projection" as prediction. Together, both of them sound extraordinarily academic, but they do not express a clear message. Some ideas are repeated in various chapters, for instance, the capacity of auto deter- 
mination of the poet, which makes the details of his regular life to be regarded as useless for him. Also, the author does not have a logical development of his arguments, which lead to a fragmented discourse. He treats the themes unequally, when he chooses to give ideas from critics, some of them are just enunciated, even thought they are innovative and, thus, important. This is the case with Th. Codreanu subjects of the lyrical Eminescian voice and the laws of the universe or the cosmological models of Ioana Em. Petrescu.

The use of pretentious words sometimes makes the message impossible to understand, or even without signification. We provide here another example: "The road of the poet to culture is the road to universality, seen as a "given thing", not as "a result". Living life at its full length is not "a purpose in itself", but a way to edification on a path like this to the searched world. His characteristics are the imaginative ubiquity, signs of the great lyric and the "lucid" way to look at the panorama of civilizations" (Cimpoi, 2013, p. 183). The cause of his death is uncertain and, also, antithetical. Cimpoi said that the poet died because of a nervous crises provoked by the news that the Carpati Society, where he was active was prohibited, and, also, because of the excessive hot weather. Another cause speculated by the critic is the process of distancing from himself and the people around him, or bad thoughts, and the ugly which makes him suffer.

The foreign dictionaries build a new figure of the national poet, different from the pattern of the majority of Romanian dictionaries, which encourage building the figure of the greatest poet ever living, or a fantastical, denaturized and confusing image of him. We will study two foreign dictionaries: Dictionnaire du romantisme 2012 [Dictionary of Romanticism 2012]; and Encyclopedia of Romantic Nationalism in Europe, ERNIE, a project coordinated by the University of Amsterdam and due to be completed at the end of 2015.

In Dictionnaire du romantisme 2012 [Dictionary of Romanticism 2012] there is a selection of the important information from the biography of the poet without using exaggerated superlatives or being subjective. So, the figure of Eminescu is placed in the general context of the epoch, being related to historical and cultural circumstances and also to prevailing settings. Referring to the data selected from his life, the critic refers to what he wrote, what he wanted to write, the status of his literary writings, most of them still kept in manuscripts and edited just in the $X X^{\text {th }}$ century. Regarding his death, what is striking here by being different from the dictionaries which present this subject just partially is the explanation: the poet suffered from a nervous malady provoked by the treatment with mercury administrated to patients with syphilis. Concerning his poetic works, Eminescu is contextualized in the literary history, being correlated with his predecessors. He is, also, compared to foreign writers like Byron, Leopardi and Victor Hugo. There are comments about the innovations of his poetry in terms of language with arguments, quoting from the poems. Finally, we have no more other critical voices pasted in the article, instead, at the end of it, we are provided with an analysis of the poet's actuality. Why he is he still modern for us today or deserves to be read nowadays?

Similar objective manner of presenting Eminescu can be observed in the second article from Encyclopedia of Romantic Nationalism in Europe signed by the same 
author, the critic Ioana Both. The poet is introduced with some important data: who he is, what he wrote, what is his place in the Romanian literature. The essential biographic information is selected in order to tell the foreign readers when was the start of his poetic career, his first published poem and, also, some data about his activity as a journalist. The critic demonstrates the specificity of Eminescu's view of nationalism related to European nationalism, how his literary writings have been received and the creation of the identity construct "national poet". The conclusions are left to the actuality and importance of his literary writings in the history of European nationalism.

Dicționarul analitic de opere literare româneşti 2007 [The analytic dictionary of Romanian literary writings 2007] proposes a new selection of literature, taking into discussion more than the old canon. For example, there are added writings less known to the Romanian public, which are being rediscovered, such as: Avatarii faraonului Tlà [The avatars of Pharaoh Tlà], Cezara [Cezara], Cum negustorii din Constantinopol [How the Constantinople merchandisers], Decebal, [Decebal], Epigonii [The epigons], Făt-Frumos din lacrimă [The beautiful-young from the tear], Floare albastră [Blue flower], Geniu pustiu [The solitary genius], Impărat şi proletar [Emperor and proletarian], Luceafärul [The evening star], Mai am un singur dor [I have one more wish], Melancolie [Melancholy], Memento mori, [Memento mori], Mira [Mira], Mureşanu [Mureşanu], Odă (în metru antic) [Ode in antic meter], Odin şi poetul [Odin and the Poet], Povestea magului călător in stele, [The story of the magician travels to the stars], Sara pe deal [Evening on the hill], Sarmis/Gemenii [Sarmis/The twins], Sărmanul Dionis [The poor Dionis], Scrisorile [The letters]. The interpretation has two parts: the first is a presentation of the poem's genesis with its variants and the place and time of publication, while the second part is dedicated to the commentaries, being taken into account the imaginary, themes/motifs, composition, the aspects referring to poetic language etc.

Therefore, the majority of the Romanian literary dictionaries with few exceptions: Dicționarul analitic de opere literare româneşti, [The analytic dictionary of Romanian literary writings 2007], Dicționarul esențial al scriitorilor români [The essential dictionary of Romanian writers 2000], Encyclopedia of Romantic Nationalism in Europe and Dictionnaire du romantisme 2012 [Dictionary of Romanticism 2012] have an important contribution to the development and perpetuation of a mythical figure of Mihai Eminescu. So, the image of the poet is used to show the geniality of a nation, in the first place, then, his own genius. Such interpretations just dismiss the true values of his creation, building him a deformed figure. The important element in this equation is given to the national character and the well known cliche "the biggest poet", explained with beautiful, but senseless words. We see, thus, what an interpretative community can do with a poet that it cannot understand, appropriating itself and taking advantage from his unique talent by adding his qualities over an entire nation. He is great, so, we, having him, must also be great. But, by not looking deep into his creations, we lose the main questions: who was Mihai Eminescu in fact and why is he important in our literature. 


\section{REFERENCES}

Bădărău, G. (2010). Dicționar de scriitori canonici români [Dictionary of Romanian canonical writers]. Iaşi: Institutul European.

Brais, A. (2008). Dicționar de literatură română şi universală. Autori. Opere. Personaje pentru elevi [Dictionary of Romanian and universal literature. Authors. Works. Characters for students]. Bucureşti: Editura Coresi.

Cimpoi, M. (2013). Mihai Eminescu - dictionar enciclopedic [Mihai Eminescu - encyclopedic dictionary]. Chişinău: Editura Gunivas.

Crețu, S., Drăgoi, G., Faifer, F., Berdan, L., Buzatu, C., Cireş, L., Ciubotaru, H. I., Mănucă, D., Morariu, C. (2005). Dictionarul literaturii române de la origini până la 1900 [The dictionary of Romanian literature from origins until 1900]. Bucureşti: Editura Academiei Republicii Socialiste România.

Encyclopedia of Romantic Nationalism in Europe, ERNIE (not yet published)

Popescu, F. (1997) Dicționar de literatură română. Autori. Opere. Personaje [Dictionary of Romanian literature. Authors. Works. Characters]. Bucureşti: Editura Saeculum.

Pop, I. (ed.) 2007. Dicționarul analitic de opere literare româneşti [The analitical dictionary of Romanian literary works]. Cluj-Napoca: Editura Casa Cărții de Ştiință.

Simion, E. (ed.) 2012. Dictionarul general al literaturii române [The general dictionary of Romanian literature]. Bucureşti: Univers Enciclopedic Gold.

Stroia I., Barbu, S. (2004). Dicționar de scriitori români şi străini. Prietenul micului cititor [Dictionary of Romanian and foreign writers. The friend of the little reader]. Bucureşti: Editura Cartea de Buzunar.

Vaillant, Alain. (ed.) 2012. Dictionnaire du romantisme [Dictionary of Romanticism]. Paris: CNRS-Sorbonne.

Zaciu, M., Sasu, A., Papahagi, M. (ed.) 2000. Dicționarul esențial al scriitorilor români [The essential dictionary of Romanian writers]. Bucureşti: Editura Albatros. 